УДК 656.222.3

\title{
ПЕРЕВЕЗЕННЯ КОНТРЕЙЛЕРІВ ДОВГОСОСТАВНИМИ І ВЕЛИКОВАГОВИМИ ПОїЗДАМИ
}

Доктори техн. наук О.В. Лаврухін, А.М. Котенко, асп. А.В. Світлична, канд. техн. наук В.І. Шевченко

\section{ПЕРЕВОЗКИ КОНТРЕЙЛЕРОВ ДЛИННОСОСТАВНЫМИ И ТЯЖЕЛОВЕСНЫМИ ПОЕЗДАМИ}

Доктора техн. наук А.В. Лаврухин, А.Н. Котенко, асп. А.В. Светличная, канд. техн. наук В.И. Шевченко

\section{THE TRANSPORTATION OF CONTRAILERS BY LONGEST AND HEAVY TRAIN}

Doct. of techn. sciences O.V. Lavrukhin, A.M. Kotenko, postgrad. A.V. Svetlichnaya, cand. of. techn. sciences V.I. Shevchenko

У статті подано аналіз досвіду впровадження руху великовагових і довгосоставних поїздів в Україні і за кордоном; визначена економічна ефективність впровадження такого виду перевезень при транспортуванні контрейлерів. Скорочення розмірів руху за рахунок збільшення составів поӥдів забезпечить зниження потреби в локомотивному парку $і$ поӥзних бригадах, зменшить кількість ремонтів тягової техніки, знизяться витрати на паливо і електроенергію.

Ключові слова: великоваговий поӥзд, пропускна спроможність, контрейлер, довгосоставний поїз, економічна ефективність.

В статье представлен анализ опыта внедрения движения тяжеловесных и длинносоставных поездов в Украине и за рубежсм; определена экономическая эффективность внедрения такого вида перевозок при транспортировке контрейлеров. Сокращение размеров движения за счет увеличения составов обеспечит снижение потребности в локомотивном парке и поездных бригадах, уменьшит количество ремонтов тяговой техники, снизятся затраты на топливо и электроэнергию.

Ключевые слова: тяжеловесный поезд, пропускная способность, контрейлер, длинносоставный поезд, экономическая эффективность.

The article presents an analysis of the experience of the implementation of the motion of heavy and longest trains in Ukraine and abroad; The economic efficiency of the implementation of this type of traffic has been defined. Reducing the size of the motion by increasing the formulations will provide the reduction of demand for locomotive fleet and crews, will reduce the number of repairs of traction equipment, reduce the cost of fuel and electricity. For sites with multiple engineering stations is possible to combine a large number of options for handling unit trains, which limits the number of equipment in technical devices, the number of stations and them elongated paths. At the expense of range following block trains without disbanding and change locomotives - the number of options for a linear direction can be reduced of two to four. Using longest trains will provide several important benefits such as: reduction of the wear tracks and wheels of the rolling stock, reduction of fuel consumption for traction increase staff productivity.

Key words: heavyweight, bandwidth, contrailers, longest train, economic efficiency.

Вступ. Відновлення економіки україни після довготривалої економічної кризи, активізація зовнішньої торгівлі внаслідок поступового відкриття європейських товарних ринків, а також загальносвітова тенденція до підвищення мобільності населення вимагають 
стабільної та ефективної роботи залізничного транспорту. В україні він забезпечує $83 \%$ загального обсягу вантажообороту та $38 \%$ пасажирообороту, а споживачі очікують від залізниці європейської якості послуг, надійності, швидкості та безпечності перевезень. Проте залізнична галузь останні декілька років демонструє негативну динаміку розвитку. Тому актуальним стає питання збільшення обсягу великовагових та довгосоставних поїздів. Перевезення напівпричепів, причепів, тобто контрейлерів, такими поїздами дозволить істотно збільшити обсяги вантажних перевезень та провізної спроможності, а також максимально ефективно використовувати залізничну інфраструктуру на ділянках 3 невисокою пропускною спроможністю.

Постановка проблеми у загальному вигляді та її зв'язок із важливими науковими та практичними завданнями. Для збільшення конкурентоспроможності залізниць та обсягу перевезень необхідно приділити першочергове значення розвитку великовагового та довгосоставного руху поїздів на великі відстані, щоб більша частка перевезень, особливо масових вантажів (вугілля, руда, зерно) припадала на залізничний транспорт.

Великий внесок у вирішення питань, пов'язаних з впровадженням руху великовагових $\mathrm{i}$ довгосоставних поїздів та розвитком контрейлерних технологій на залізницях України, зробили такі вчені: Т.В. Бутько, Н.А. Воробйов, Ю.В. Дьяков, А.М. Котенко, В.Є. Козлов, П.С. Шилаєв та багато інших.

У роботі [1] наведені відомості про протяжності великовагових залізниць різних країн, їх вантажонапруженість, масу поїздів, число вагонів і осьове навантаження. Крім технології вивезення корисних копалин 3 місць видобутку в місця навантаження на інші види транспорту або в місця їх споживання, виявилося, що важковаговий рух дає великі економічні переваги при перевезенні вантажів у двоповерхових контейнерах. Тим самим важковаговий рух займає істотне місце в глобалізації вантажних транспортних перевезень.

У роботі [2] наведено удосконалену методику для розрахунку раціональної кількості великовагових поїздів для залізничного напрямку. Це дозволяє збільшити провізну спроможність залізничної лінії.
На основі результатів вищезгаданих наукових робіт $\epsilon$ потреба у вивченні досвіду українських залізниць при впровадженні руху великовагових i довгосоставних поїздів в Україні, а також у визначенні економічної ефективності при впровадженні такого виду перевезень при транспортуванні контрейлерів.

Визначення мети та задачі дослідження. Метою даної статті є аналіз досвіду впровадження руху великовагових i довгосоставних поїздів в Україні і за кордоном; вибір найбільш ефективної схеми формування поїздів збільшеної маси і довжини; визначення економічної ефективності впровадження такого виду перевезень при транспортуванні контрейлерів.

Основна частина дослідження. До основних переваг використання великовагових поїздів можна віднести підвищення провізної спроможності при незмінній пропускній спроможності мережі. Для впровадження руху великовагових та довгосоставних поїздів виникає ряд невирішених питань. А саме вибір ділянок залізниці, які дозволять пропуск такого виду поїздів, питання, пов'язані 3 водінням довгосоставних та великовагових вантажів. Для таких перевезень потрібно відповідне технологічне забезпечення та стан інженернотранспортної інфраструктури.

На залізницях світу 3 великоваговим рухом були досягнуті максимальні показники : маса поїзда - 48000 т, число вагонів - 320-340, осьове навантаження - 37-40 тс/вісь (Австралія), вантажонапруженість - 300 млн т брутто (Китай). В даний час в Західній Європі можна констатувати наявність двох залізничних ліній, де $\epsilon$ регулярний великоваговий рух. Одна з них - рудовозна лінія Лулео - Нарвік протяжністю 560 км, експлуатується спільно Швецією та Норвегією. Видобута в Швеції залізна руда перевозиться до норвезького експортного порту Нарвік 68-вагонними поїздами масою брутто 8500 т. Інша лінія, протяжністю близько 200 км, з'єднує порт Гамбург 3 металургійним комплексом Зальцгиттер. Допустиме осьове навантаження тут становить 25 т. 31999 р. імпортована руда доставляється до металургійного комплексу в поїздах масою брутто понад 5 тис. т [1].

Широко розповсюджено використання великовагових і довгосоставних поїздів у таких країнах, як Канада, Китай, Індія, США. 
Стратегія залізниць Канади спрямована на розширення використання довгосоставних поїздів. Різносторонні дослідження і інвестиції в реалізацію сучасних технологій у галузі колійного, локомотивного, вагонного господарств, засобів автоматизації і систем управління спрямовані на вирішення завдань організації впровадження поїздів довжиною 4,3 км.

Істотним фактором, який сприяє впровадженню технології водіння довгосоставних поїздів, $є$ застосування розподіленої тяги, що дозволяє знизити рівень поперечних сил при взаємодії рухомого состава i колії в кривих. На теперішній час на залізницях Canadian Pacific розподілена тяга використовується для поїздів, які перевозять вантажі різних категорій, при цьому для тяги поїздів особливо великої маси зазвичай застосовуються два локомотиви 33000 кВт у голові поїзда, один в середині і один у хвості [7] (рис. 1).

Водіння довгосоставних поїздів 3 використанням розподіленої тяги має особливе значення в складних погодних умовах, зокрема взимку, коли низькі температури повітря ускладнюють роботу гальмівної системи.

В Україні накопичений певний досвід роботи з великоваговими поїздами. Почався він з 1975 р. на сприятливому профілі ділянки Кременчук - Полтава. Один тепловоз вів два зчеплених поїзди вагою більш 7200 т.
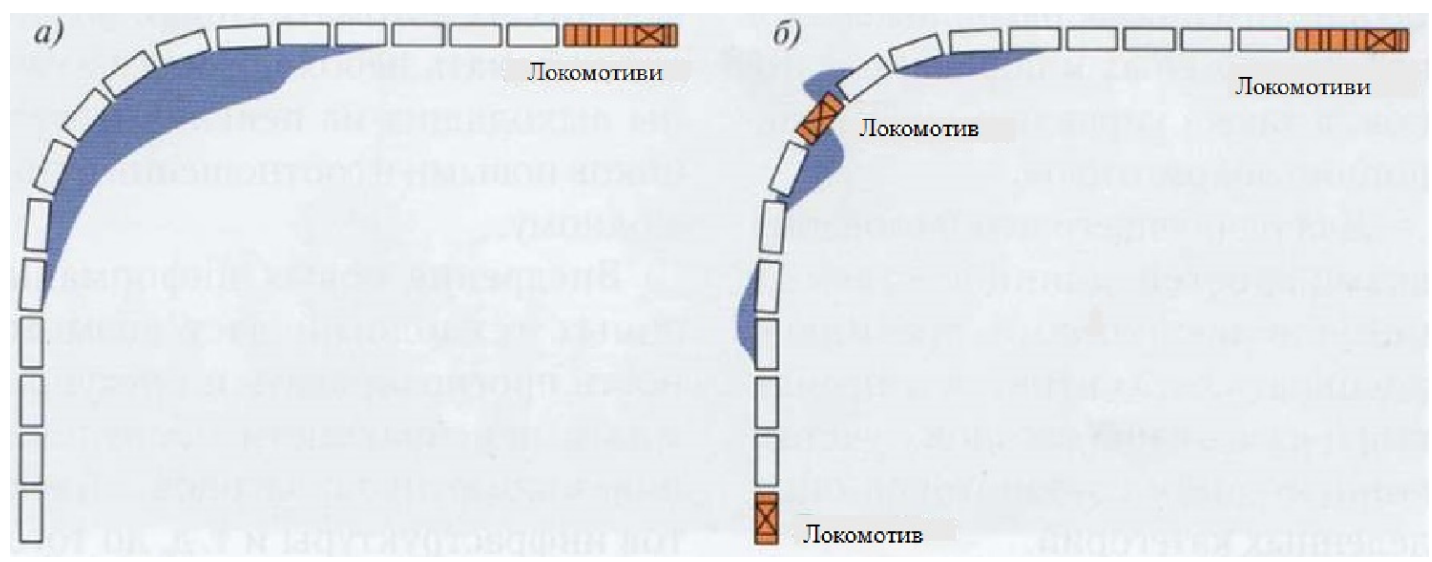

Рис. 1. Варіанти розміщення локомотивів у складі поїзда:

$\mathrm{a}$ - локомотиви в голові поїзда; б - локомотиви в голові, середині і у хвості поїзда

У 1985 р. на ділянці Кременчук - Полтава був організований пропуск рудного маршруту вагою 13200 т. Результатом такого випробування було підвищення продуктивності вагона до $111.7 \%$, або 8000 ткм; продуктивність локомотива за добу складала 1216 ткм; 3268 т була вага поїзда; статистичне навантаження на вагон було 59.3 т [1]. Також був організований пропуск здвоєних поїздів на ділянці Гребінка Полтава, до складу яких входили 200 вагонів 3 одним локомотивом. За рахунок скорочення одного поїзда на ділянці виникають умови для пропуску чергових поїздів 3 випередженням графіка.

Обсяги перевезень стрімко падають. У 2013 р. порівняно із 2012 р. Обсяг вантажних перевезень залізничним транспортом зменшився на $3,4 \%$ і становив 441,8 млн т вантажів (або $86 \%$ від рівня 2007 р.) При цьому за 2013 р. транзитні перевезення скоротилися на $19,3 \%$, перевезення у внутрішньому сполученні - на 2,8\%, імпорт вантажів - на $2,7 \%$, збільшено лише обсяг перевезень експортних вантажів на $2 \%$. В поточному році ця тенденція продовжується і за дев'ять місяців 2014 р. Падіння обсягів перевезень вантажів становить $7,8 \%$ порівняно 3 аналогічним періодом 2013 p.

Одним 3 перспективних напрямків підвищення пропускної та провізної спроможності ділянки є реалізація технології керування довгосоставних i великовагових поїздів. Використання довгосоставних поїздів дозволить отримати ряд важливих переваг: зменшення зносу колії і коліс рухомого складу, скорочення споживання палива на тягу поїздів, 
підвищення продуктивності праці персоналу. При розгляді варіантів пропуску поїздів підвищеної маси і довжини розглядається принцип розробки технічної основи спільного пропуску поїздів різної маси i довжини 3 найменшою перебудовою технічної бази лінії і зміною локомотивного парку, що скоротить капітальні вкладення в технічну реконструкцію лінії [4].

Для ділянок 3 декількома технічними станціями можна скомбінувати велику кількість варіантів обігу поїздів підвищеної маси i довжини, число яких обмежує

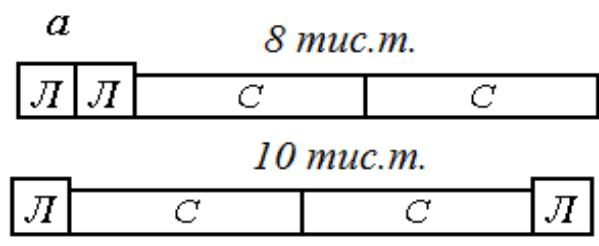

Л-локомотие оснащеність в технічних пристроях, число станцій перетворення і подовжених на них шляхів. За рахунок дальності слідування поїздів підвищеної маси i довжини без розформування та зміни локомотивів - число варіантів для лінійного напряму може скоротитися до двох-чотирьох. Поїзди підвищеної маси і довжини включають два i більше состави стандартної довжини або встановленої маси з розташованими між ними локомотивами. Нижче (рис. 2) наведені варіанти формування поїздів [13].

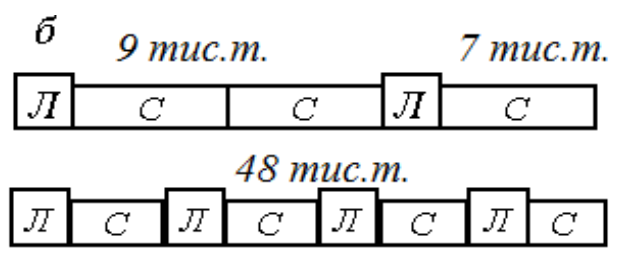

Рис. 2. Варіанти формування поїздів

Розглянемо економічну ефективність транспортування контрейлерів довгосоставними і великоваговими поїздами і автомобілем. Контрейлер - це контейнер, обладнаний колесами 3 пневматичними шинами і призначений для перевезення вантажу на залізничних платформах і по шосе. Його вантажопідйом- ність складає 6-30 т [10]. Витрати на транспортування контрейлерів поїздом складаються 3 експлуатаційних витрат на станціях обробки складу, а також з експлуатаційних витрат на шляху прямування поїзда [9].

Сумарні залежні експлуатаційні витрати, пов'язані з проходженням за маршрутом поїзда,

$$
B_{\text {прox }}=B_{6-\kappa u}+B_{6-2}+B_{u-\kappa u}+B_{\text {бp- }}+B_{m-\kappa u}+B_{m},
$$

де $B_{\text {в-ки }}{ }^{-}$витрати, пов'язані 3 вагонокілометрами пробігу, тис. грн;

$B_{6-2}$ - витрати, пов'язані з вагоно-годинами, тис. грн;

$B_{\text {л-км }}$ - витрати, пов'язані 3 локомотивокілометрами, тис. грн;

$B_{\text {бр-г }}$ - витрати, пов'язані 3 локомотивогодинами, тис. грн;

$B_{m-\kappa м}$ - витрати, пов'язані з бригадо-годинами роботи локомотивних бригад, тис. грн;

$B_{m}$ - витрати, пов'язані 3 витратами палива (електроенергіï) на тягу поїзда, тис. грн;
Залежні експлуатаційні витрати, пов'язані 3 проходженням технічних станцій при організації руху поїздів,

$$
B_{\text {mex.cm. }}=\zeta 10^{-3} T^{\text {mex }} c_{\theta_{-2}} K
$$

де $T^{\text {mex }}$ час на операції на технічній станції, год;

$\mathcal{C}_{\varepsilon_{-2}}$ - видаткова ставка на 1 ваг.год, грн;

$K$ - кількість контрейлерів.

Залежні експлуатаційні витрати, пов'язані 3 обробкою поїзда на станціях примикання, 


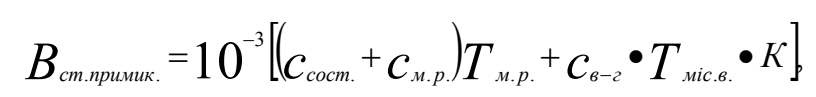

де $\boldsymbol{C}_{\text {coсm. }}$ - видаткова ставка на 1 год роботи складача поїзда, грн;

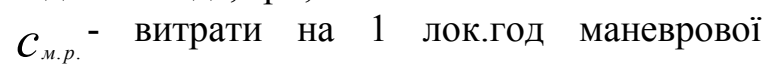
роботи, грн;

$T_{\text {м.р. }}$ - витрати часу на маневрову роботу на станції примикання, год;

$T_{\text {міс.в. }}$ - середній простій місцевого вагона на станції примикання.

$$
\text { Витрати на транспортування }
$$
контрейлерів автомобільним транспортом

$$
C_{\text {asm. }}=V+F+T+M+H+R+A+N V,
$$

де $V$ - витрати на оплату праці водія, грн;

$F$ - відрахування в соціальні фонди, грн;

$T$ - витрати на автомобільне паливо, грн;

$M$ - витрати на мастильні й інші матеріали, грн;

$H$ - витрати на ремонт автомобільних шин, грн;

$R$ - витрати на технічне обслуговування i ремонт автомобіля, грн;

$A$ - амортизаційні відрахування, грн;

$N V$ - накладні витрати.

Економічна ефективність при впровадженні довгосоставних і великовагових поїздів досягається за рахунок повного виключення витрат на палива, мастила, ремонт автомобільних шин, коліс, що складає приблизно 20\% у структурі собівартості автомобільних перевезень. Також важливим фактором $\epsilon$ те, що існують жорсткі вимоги до ваги автомобілів на автошляхах як нашої країни, так і інших країн Свропи.

Відомо, що близько $30 \%$ всіх експлуатаційних витрат припадає на частку локомотивного господарства. Скорочення розмірів руху за рахунок збільшення составів поїздів забезпечить зниження потреби в локомотивному парку i поїзних бригадах, зменшить кількість ремонтів тягової техніки, знизяться витрати на паливо і електроенергію. Збільшення составів поїздів на великих полігонах стає вирішальним заходом зниження капіталомісткості і собівартості перевезень. Подальше впровадження цієї технології в поєднанні 3 іншими прогресивними методами організації перевізного процесу дозволить залізницям України стабільно забезпечувати перевезення пасажирів і вантажів у необхідних обсягах з високою економічною ефективністю.
На сьогоднішній день Укрзалізниця працює над створенням електрифікованого ходу певних дільниць. Це дозволить залізничникам збільшити обсяги перевезень на порти, а використання електровозів замість тепловозів створить можливість відправляти великовагові поїзди із максимально допустимою кількістю вагонів, які будуть вести більш потужні локомотиви.

Завдяки електрифікації швидкість руху вантажних поїздів на дільниці збільшиться на 20-25\%, скоротиться час доставки вантажів. Електрифікація дасть змогу запропонувати вантажовідправникам більш вигідне транспортування, у тому числі i за рахунок зменшення собівартості перевезень, яка на 55$60 \%$ нижча, ніж на теплотязі. Переведення напрямку на електротягу дозволить залізниці скоротити споживання дизпалива у 3,7 рази. До того ж використання електровозів замість тепловозів дасть можливість відправляти великовагові поїзди із максимально допустимою кількістю вагонів і більш потужними локомотивами. Щоб оптимально використовувати наявну інфраструктуру, доцільно впроваджувати великовагові поїзди в Україні. Впровадження нових технічних систем на рухомому складі не вимагає великих витрат часу i економічно набагато ефективніше проектування і будівництва об'єктів нової інфраструктури.

Важливою вимогою до інфраструктури $\epsilon$ достатня протяжність двоколійних ділянок або обгінних пунктів, які дозволять приймати поїзди довжиною до 4 км. Маршрути курсування довгосоставних i великовагових поїздів слід обирати по більш вантажонапружених залізничних лініях, дивлячись на обсяги перевезень таких вантажів: кам’яне вугілля, залізна руда. 
В структурі вантажних залізничних перевезень понад $60 \%$ припадає на масові вантажі, які транспортуються великими партіями на значні відстані - вугілля (19\%), руда $(27 \%)$, будматеріали $(14 \%)$, кокс $(2 \%)$, зерно і продукти помелу (9\%) та ін. [3]. Прогнозується значне збільшення обсягів перевезень насамперед на тих напрямках, які забезпечують доставку вантажів у морські порти країни, а також в регіонах зі значним зростанням вантажної бази (рис. 3). За 2015 р. Південною залізницею було відправлено близько 190 поїздів масою 8000 т.

\section{Відправлення вантажів залізничним транспортом за 2015 рік}

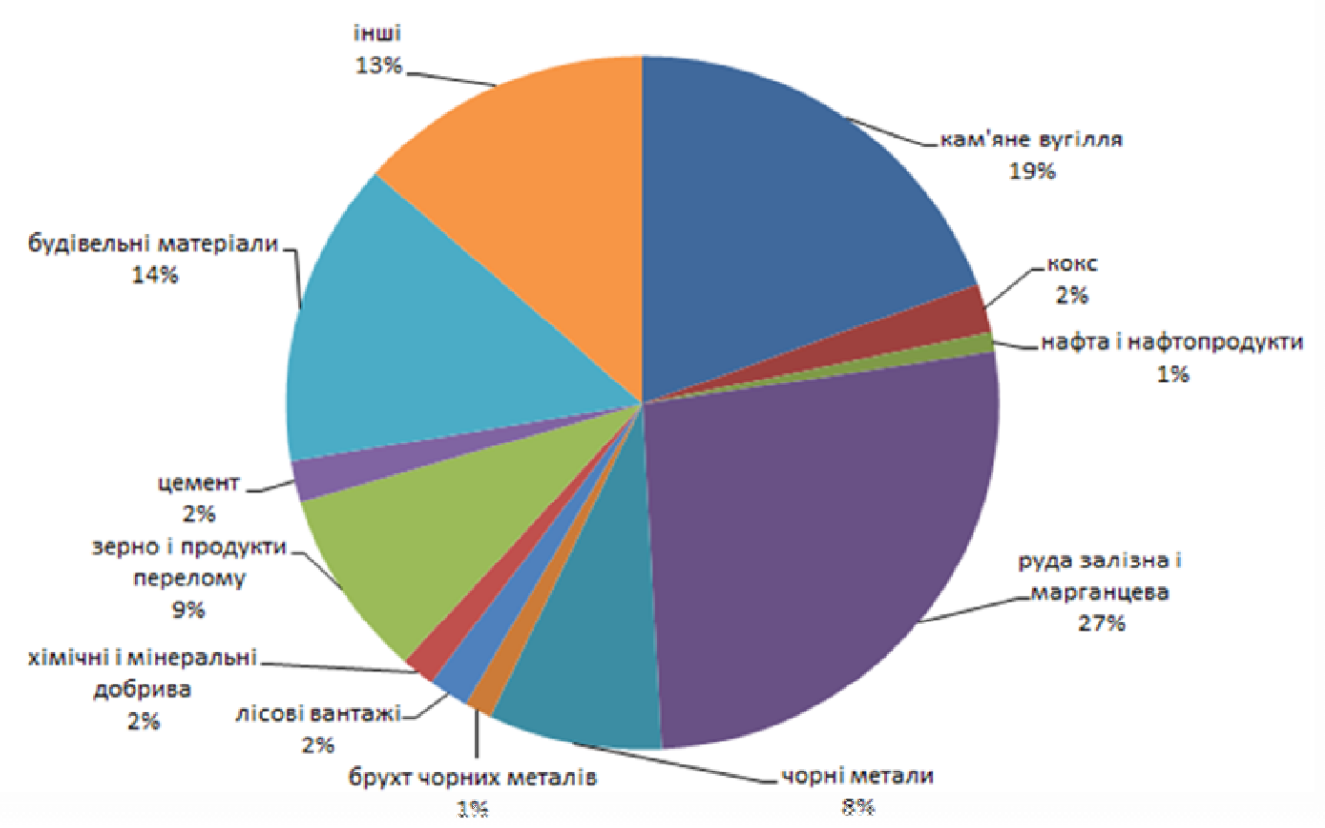

Рис. 3. Відправлення вантажів залізничним транспортом за 2015 рік

Перспективними напрямами співробітництва України і $\mathrm{CC} є$ залучення додаткових обсягів транзитних вантажопотоків за рахунок впровадження перевезень контрейлерів великоваговими і довгосоставними поїздами не тільки територією України, а і нових напрямків руху: Європа - Кавказ - Азія; ТРАСЕКА (Великий Шовковий шлях); Чорне море Балтійське море із залученням додаткових вантажопотоків 3 Туреччини (у прямому напрямку) та із Скандинавських країн (у зворотному напрямку).

У світовій практиці простежується неухильна тенденція вдосконалення технології вантажних перевезень, пов'язана 3 концентрацією транспортних потоків i зростанням контрейлерних $\mathrm{i}$ контейнерних перевезень по інтермодальних транспортних коридорах, які повинні стати основою єдиної глобальної транспортної мережі XXI століття, створення i функціонування якої $€$ одним 3 головних завдань євроазіатської транспортної політики.

Розвиток великовагового руху дозволить значно збільшити середню вагу поїзда, середньодобову продуктивність локомотивів i ефективно використовувати їх потужність. Крім того, знизяться експлуатований парк локомотивів і кількість локомотивних бригад, вивільняться «нитки» графіка для підвищення пропускних i провізних спроможностей полігонів мережі.

Висновки 3 дослідження і перспективи, подальший розвиток у даному напрямку. Як 3 економічної, так і з екологічної точок зору, вантажні залізничні перевезення вважаються найбільш переважними, принаймні при перевезеннях масових вантажів на далекі відстані. Щоб оптимально використовувати наявну інфраструктуру, доцільно впроваджувати поїзди підвищеної маси i довжини. Впровадження нових технічних систем на рухомому складі не вимагає великих витрат 


\section{Експлуатація залізниць}

часу i економічно набагато ефективніше проектування і будівництва об'єктів нової інфраструктури. У найближчі десятиліття клієнтура отримає особливо привабливі рішення проблеми залізничних перевезень, що базуються на таких системах.

\section{Список використаних джерел}

1. Захаров, С.М. Развитие тяжеловесного движения в мире [Текст] / С.М. Захаров, К.П. Шенфельд // Вестник ВНИИЖТ. - 2013. - №4. - С. 9-18.

2. Безопасность движения поездов при организации тяжеловесного движения [Текст] / Тематическая подборка. - Екатеринбург, 2012. - 30 с.

3. Відправлення вантажів залізничним транспортом [Електронний ресурс]. - Режим доступу: http://ukrstat.gov.ua/operativ/operativ2015/tz/opr/opr_u/opr0715_u.htm.

4. Бутько, Т.В. Формування методики визначення кількості великовагових поїздів на залізничному напрямку [Текст] / Т.В. Бутько, Д.О. Григоренко // Зб. наук. праць Укр держ. акад. залізнич. трансп. - Харків: УкрДАЗТ, 2013. - Вип.140. - С. 48-55.

5. Укрзалізниця працює над створенням електрифікованого ходу [Електронний ресурс]. Режим доступу: http://uz.gov.ua/press_center/up_to_date_topic/317864/.

6. Блохин, Е.П. Исследование продольной нагруженности длинносоставных грузовых поездов при торможении [Текст] / Е.П. Блохин Л.В. Урсуляк Я.Н. Романюк // Наука и прогресс транспорта. 2011. - №38. - С. 7-16.

7. Вождение тяжеловесных и длинносоставных поездов [Электронный ресурс]. - Режим доступа: http://refsurf.ru/1920130982.html.

8. Водіння великовагових поїздів через перевали за маршрутом Коломия-Рахів Львівської залізниці у 50-60-ті роки минулого століття [Електронний ресурс]. - Режим доступу: http://railman.com/zhittja/novina/article/vodinnja-velikovagovikh-pojizdiv-cherez-perevali-za-marshr/.

9. Климова, Н.В. Экономическая оценка вариантов транспортировки судовой партии контейнеров автомобильным и железнодорожным транспортом [Текст] / Н.В. Климова // Экономика железных дорог. - 2013. - №11. - С. 62-72.

10. Світлична, А.В. Аналіз шляхів розвитку комбінованих перевезень в Україні [Текст] / А.В. Світлична // Зб. наук.праць Укр. держ. акад. залізнич. трансп. - Харків: УкрДАЗТ, 2012. - Вип 13.

11. Проект Marathon: длинносоставные поезда во Франции [Электронный ресурс]. - Режим доступа: http://www.zdmira.com/news/proektmarathondlinnosostavnyepoezdavofrancii.

12. Курбасов, А.С. Тяжеловесное движение грузовых поездов на российских железных дорогах: за и против [Текст] / А.С. Курбасов // Наука и транспорт. - № 3.- 2012.- С.15-17.

13. Технология формирования и пропуска поездов повышенной длины и массы [Электронный pecypc]. - Режим доступа: http://vunivere.ru/work46620/page16.

Лаврухін Олександр Валерійович, доктор технічних наук, професор, завідувач кафедри управління вантажною і комерційною роботою. Тел. 730-10-85.

Котенко Анатолій Миколайович, доктор технічних наук, професор, кафедра управління вантажною $\mathrm{i}$

комерційною роботою. Тел. 730-10-85.

Світлична Аліна Володимирівна, аспірант, кафедра управління вантажною і комерційною роботою. Тел. 730-10-85.

Шевченко Віталій Іванович, кандидат технічних наук, кафедра управління вантажною і комерційною роботою.

Тел. 730-10-85.

Lavruhin Oleksandr Valeriyovich, doct. of techn. sciences, professor, head of the Department of freight and commercial work, Ukrainian State University of Railway Transport, tel. 730-10-85.

Kotenko Anatoliy Mikolayovich, doct. of techn. sciences, professor, department of freight and commercial work, Ukrainian State University of Railway Transport, tel. 730-10-85.

Svetlichnaya Alina Volodymyrivna, postgraduate, Department of freight and commercial work, Ukrainian State University of Railway Transport, tel. 730-10-85.

Shevchenko Vitaliy Ivanovich, cand. of techn. sciences, Department of freight and commercial work, Ukrainian State University of Railway Transport, tel. 730-10-85.

Стаття прийнята 16.09 .15 p. 